\title{
Design of national meat and vegetable products for baby food
}

\author{
Anna Vasyukova $^{1 *}$, Valeriy Karpov ${ }^{2}$, Erac Makhmadaliyev ${ }^{1}$, Nina Valentinova ${ }^{1}$, \\ Svetlana Yegorova ${ }^{3}$ \\ ${ }^{1}$ K.G. Razumovsky Moscow State University of technologies and management (the First Cossack \\ University), Department of Personalized Dietetics, Hotel and Restaurant Business, 109316 Talalikhina \\ street 31, Russia \\ ${ }^{2}$ KG Razumovsky Moscow State University of technologies and management (the First Cossack \\ University), Department of Information systems and technologies, 109004Zemlyanoy Valstreet 73, \\ Russia \\ ${ }^{3}$ KG Razumovsky Moscow State University of technologies and management (the First Cossack \\ University), Department of Technologies of grain processing, bakery, pasta and confectionery \\ production, 109316 Talalikhina street 31, Russia
}

\begin{abstract}
The article presents studies on the optimization of recipes and nutritional value of national meat and vegetable products enriched with vegetable products: cabbage, carrots and pumpkin, for the nutrition of schoolchildren of 7-11 years old. Using the method of mathematical modeling, a reference sample, a blend was determined, and the formulation of a multicomponent protein-containing product was optimized.The method of selection of components was used to select promising ingredients for combining traditional recipes for minced meat. It was found that pumpkin, zucchini,cabbage and carrots. On theon the basis of organoleptic and physicochemical studies for the production of model minced meat were selected vegetable components in the ratio of meat: vegetable raw materials for blend No. 1 62: 34, and for blend No. 2 65: 29. The recipe was optimized by the method of integer nonlinear mathematical programmingfor the optimality criterion of blend No. $1, \mathrm{k}=2.04$, and for blend No. $2, \mathrm{k}=0.81$. Received,The recipe for meat and vegetable minced meat in terms of the ingredient composition will be as close as possible to the reference sample, which is $10 \%$ of the daily set of food products for the nutrition of schoolchildren of the age category 7-11 years.
\end{abstract}

\section{Introduction}

Currently, the most important are the requirements for food supply of the population, which have acquired signs of diversification and specialization.

In line with "The concept of demographic policy of the Russian Federation for the period up to 2025" [1], as well as in the Federal Law N 29-FZ "On the quality and safety of food" [2] the goals of the state policy in the field of healthy nutrition proclaimed the preservation and strengthening of public health, the prevention of diseases associated with malnutrition of

\footnotetext{
* Corresponding author: vasyukova-at@ yandex.ru
} 
children and adults. Defined as a strategic goal, the formation in the country of the foundations of the healthy food industry, including an increase in the production of new fortified, dietary and functional food products aimed at meeting the needs of the population.

Scientific research of the state of human health in the developed countries of the world shows exceptional changes in the structure of nutrition of a modern citizen. The Strategy of Nutrition and Physical Activity in the Republic of Tajikistan for 2015-2024 [3] is also aimed at one of the most serious, global problems of a healthy population in the country - insufficient nutrition and low attention to it. The current economic shortcomings in the country affect most often poor families, women and children, which lead to damage to health and loss of life.

According to the academician of the Academy of Medical Sciences D.F. Chebotareva, "nutrition is practically the only means that prolongs the species life expectancy by $20-40 \%$ " [4]. According to experts, the health of the nation depends only on $9-12 \%$ of the health care system.

In human nutrition, the biological value of various products is the most important indicator in assessing the actual nutritional value and digestibility of a particular product [5-8]. The most important at present is the creation of environmentally friendly food products based on raw materials of animal and plant origin. Therefore, an important factor remains the initial raw material, and the creation on its basis of meat-containing culinary products with specified consumer properties for production in public catering and food industries. The use of natural plant materials as auxiliary ingredients in the combined minced meat will allow a range of culinary products with high nutritional value and long shelf life.

Vegetable raw materials are rich in minerals and vitamins, dietary fiber, proteins, macro and microelements. The exceptional chemical composition of the presented additives improves the taste and nutritional value of culinary meat products.

The absence of the necessary components in food leads to a decrease in the nonspecific resistance of the organism and the development of immunodeficiency states. The consequence of this was a decrease in the volume and a change in the range of food consumed by humans. As a result, the provision of a person with essential nutrients has changed in an unfavorable direction. To maintain the body's performance in such conditions, it is important to be more careful about the level of intake of various nutrients from everyday foods. Hence the growing popularity of fortified foods, the compositions of which are specifically designed to replenish the nutritional profile of the diet [5-8]. One of the most developing areas in the meat industry is currently the production of semi-finished products. Chopped semi-finished products are products prepared as much as possible for heat treatment, they are products of a high degree of readiness, which in modern conditions makes them highly demanded for the consumer. Of particular importance is the development of recipes and technologies for new combined semi-finished products with high biological value based on the combination of meat raw materials with proteins of animal and vegetable origin.

In this regard, it is promising to develop multicomponent food products based on raw materials of both animal and plant origin, used in the production of various food products to improve their quality by increasing the nutritional balance and the availability of dietary fiber.

Meat products, the consumption of which is constantly increasing in the diet of the population of our country, occupy an important place. This is due to the high consumer properties of this type of product, minimal time spent on bringing them to a state of readiness and relatively low cost. Considering that meat products are popular and consumed in large quantities, it seems possible to realistically and effectively prevent various types of diseases by producing products using combinations of animal and plant raw materials containing a balanced complex of proteins, macro and microelements, and vitamins. 
An analysis of recipes and technological schemes for the production of minced meat products showed that the introduction of various functional and structural fillers and additives into minced meat is widely used in public catering enterprises and in the food industry. This allows you to obtain the desired structural and mechanical properties, taste, color, odor, change the chemical composition, food and biological value, finished product yield. Thus, the rational use of meat and vegetable raw materials in one culinary product, scientific substantiation of the technology of meat and vegetable and meat-containing semi-finished products and culinary products, the use of the most common local raw materials in relation to new resource-saving innovative equipment is very important at the present time.

The creation of combined meat food products, providing for the rational use of raw materials on the basis of assortment and recipe optimization, the selection of recipes for the chemical composition of the recipe components of the product, the development and introduction of new types of products balanced in amino acid composition, and the use of modeling methods is relevant. The sale of minced meat products based on a combined meat product with herbal additives makes it possible to reduce the need of domestic producers from foreign partners and effectively use meat resources in the country.

\section{Materials and methods}

The purpose of this work is the development of recipes and commodity assessment of meat and vegetable model minced meat and semi-finished products using vegetable raw materials.

To achieve this goal, the following tasks were identified:

- to substantiate the choice of meat raw materials for the development of specialized meat and vegetable semi-finished products in order to increase their biological value and efficiency;

- in the formulations of the developed meat and vegetable semi-finished products, to study the nutritional value of herbal additives in comparison with traditional structure-formers;

- using the method of computer-aided design to develop recipe compositions of fortified meat and vegetable semi-finished products, taking into account their minimum cost and high nutritional value.

A new assortment of minced meat with herbal additives was developed by the method of selection of recipe components and the requirements of GOST 32691-2014. In the manufacture of model minced meat, the following vegetables were used: white cabbage, zucchini, pumpkin, carrots, cilantro. Three options are offered as raw meat: beef, mutton and minced beef and mutton.

In accordance with SanPiN 3590-20 the diet of students 7-11 years old includes 3 main meals: breakfast, lunch and dinner: $25-35-30 \%$ (standard). Each meal consists mainly of 3-4 meals.

\section{Results and discussion}

To select target food groups that can be positioned as products with a simulated nutrient composition, studies were carried out to identify the functional properties and compatibility of meat and vegetables in one product.

Let's say that 1 dish will be $10 \%$ of the total diet. Therefore, for the age category of 7-11 years, we obtain the value of nutrients and energy, presented in table. 1 (standard and blend).

However, in order to develop a recipe for meat and vegetable mince, it is necessary to select the required vegetable raw materials that satisfy the physiology of children's nutrition and the rational use of food products. 
As a result of the study, it was found that vegetable raw materials contain protein in the range of $0.62 \ldots 1.13 \%$, fat $-0.12 \ldots 0.41 \%$, carbohydrates $-4.63 \ldots 10.21 \%$, dietary fiber $1.1 \ldots 2.6 \%$, of the mineral substances the most potassium is $235 \ldots 278 \mathrm{mg}$. Sodium, calcium, magnesium, phosphorus are contained in small amounts. Of the trace elements, iron can be noted, the concentration of which in vegetables is $0.39 \ldots 0.45 \mathrm{mg}$, and in apples $-2.23 \mathrm{mg}$. Of the vitamins, a high concentration of ascorbic acid - $5 \ldots 32 \mathrm{mg}$ and $\beta$-carotene - $20 \ldots 150 \mathrm{mg}$. The energy value of this raw material is from 25 to $50 \mathrm{kcal}$. [13]

To substantiate the use of the proposed promising herbal ingredients, we made a comparative analysis of the nutritional value of traditional herbal raw materials included in the recipes of meat and vegetable mince and recommended. The research results are presented in table.2.

It was found that all offered vegetables (White cabbage,carrot, zucchini, cilantro and pumpkin) enrich minced meat, the recipes of which include bread, onions, garlic, with the following components: $\beta$ carotene in the range of $19.08 \ldots 149.99 \mathrm{mg}$ per $100 \mathrm{~g}$ of product; vitamins B1 - $0.02 \ldots 0.06 \mathrm{mg}$ (individual vegetables); $\mathrm{C}-1.0 \ldots 27.0 \mathrm{mg}$ (selected vegetables); dietary fiber - $0.2 \ldots 1.2 \mathrm{~g}$; minerals: sodium - $1.0 \ldots 24.0 \mathrm{mg}$ (individual vegetables) and iron $-1.33 \ldots 1.63 \mathrm{mg}$ (individual vegetables). The introduction of carrots into the recipes helps to increase the calorie content of casseroles by 9 ... $22 \mathrm{kcal}$ The combination of meat components with vegetable raw materials made it possible to obtain a new assortment of meat and vegetable mince with vitamins, mineral and ballast (fiber) substances, which made it possible to use it as a functional product[14 - 16]... 
Table 1. Nutritional value of the standard and minced meat.

\begin{tabular}{|c|c|c|c|c|c|c|c|c|c|c|c|c|c|c|c|c|}
\hline $\begin{array}{c}\text { Product } \\
\text { name }\end{array}$ & $\begin{array}{l}\text { Pro- } \\
\text { tein } \\
s(g)\end{array}$ & $\begin{array}{c}\text { Fat } \\
\text { (g) }\end{array}$ & $\begin{array}{c}\text { Car- } \\
\text { bohy- } \\
\text { drates } \\
\text { (g) }\end{array}$ & $\begin{array}{c}\text { EC } \\
\text { (kcal) }\end{array}$ & $\begin{array}{c}\text { Vita- } \\
\text { min } \\
\text { B1 } \\
(\mathbf{m g})\end{array}$ & $\begin{array}{c}\text { Vita- } \\
\text { min } \\
\text { B2 } \\
(\mathbf{m g})\end{array}$ & $\begin{array}{c}\text { Vita- } \\
\text { min C } \\
(\mathrm{mg})\end{array}$ & $\begin{array}{c}\text { Vita- } \\
\text { min A } \\
(\mathbf{m g} \\
\text { ret.eq) } \\
/ \beta\end{array}$ & $\begin{array}{c}\text { Vita- } \\
\text { min } \mathrm{E} \\
(\mathrm{mg} \\
\text { cur- } \\
\text { rent } \\
\text { equiv.) }\end{array}$ & $\begin{array}{c}\text { Calciu } \\
\mathbf{m} \\
(\mathrm{mg})\end{array}$ & $\begin{array}{c}\text { Phosp } \\
\text { horus } \\
(\mathrm{mg})\end{array}$ & $\begin{array}{c}\text { Magn } \\
\text { esium } \\
(\mathrm{mg})\end{array}$ & $\begin{array}{l}\text { Iron } \\
(\mathbf{m g})\end{array}$ & $\begin{array}{l}\text { Dietary } \\
\text { fiber, } g\end{array}$ & $\begin{array}{c}\mathbf{d}= \\
\text { sum } \\
\text { sq. }\end{array}$ & $\begin{array}{l}\text { criterio } \\
\mathbf{n}=\mathbf{s q r} \\
\text { (d) }\end{array}$ \\
\hline $\begin{array}{l}\text { REFEREN } \\
\text { CE }\end{array}$ & 7,7 & 7.9 & 33.5 & 235 & 0.12 & 0.14 & 18.3 & 0.07 & one & 110 & 165 & 25 & 1,2 & 3.33 & & \\
\hline Blend & 21.6 & 23.3 & 86 & 700 & 0.43 & 0.33 & 23.3 & 0.167 & 5.93 & 166 & 400 & 100 & 5.67 & 6.01. & & 2.04 \\
\hline $\begin{array}{l}\text { beef } \\
\text { category } 1\end{array}$ & 18.9 & 16.0 & 0 & 218 & 0.06 & 0.15 & 0 & 0 & 0,4 & 9.0 & 188 & 22 & 2.7 & 0 & & \\
\hline $\begin{array}{l}\text { lamb } \\
\text { category } 1\end{array}$ & 15.6 & 16.3 & 0 & 209 & 0.08 & 0.14 & 0 & 0 & 0.6 & 9.0 & 168 & 12.0 & 2 & 0 & & \\
\hline $\begin{array}{l}\text { White } \\
\text { cabbage }\end{array}$ & 1.8 & 0.2 & 4.7 & 28 & 0.03 & 0.07 & 60 & 0.06 & 0.1 & 48 & 31 & 16.0 & 0.6 & 2 & & \\
\hline $\begin{array}{l}\text { wheat bread } \\
1 \text { grade }\end{array}$ & 13.4 & 5.3 & 67.5 & 395 & 0.97 & 0,4 & 0 & 0 & 0.08 & 183 & 165 & 43 & 4.83 & 4.5 & & \\
\hline butter & 1.0 & 72.5 & 1.4 & 662 & 0.01 & 0.1 & & 0.65 & 1.0 & 12 & 19.0 & 0,4 & 0.2 & 0 & & \\
\hline cilantro & 2.1 & 0.5 & 0.9 & 23 & 0.067 & 0.162 & 27 & 0.337 & 2.5 & 67 & 48 & 26 & 1.77 & 2.8 & & \\
\hline
\end{tabular}


Table 2. Comparative analysis of the nutritional value of plant raw materials, traditional and recommended for the developed formulations of meat and vegetable mince (white cabbage).

\begin{tabular}{|c|c|c|c|c|c|c|c|c|c|}
\hline \multirow{2}{*}{$\begin{array}{l}\text { Name of } \\
\text { food } \\
\text { substances }\end{array}$} & \multirow{2}{*}{ 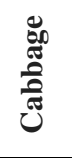 } & \multicolumn{2}{|c|}{ Pumpkin } & \multicolumn{2}{|c|}{ Carrot } & \multicolumn{2}{|c|}{$\begin{array}{l}\text { Onion } \\
\text { onion }\end{array}$} & \multicolumn{2}{|c|}{ Zucchini } \\
\hline & & $\begin{array}{l}\text { con- } \\
\text { tent }\end{array}$ & $\begin{array}{c}\text { devia- } \\
\text { tion }\end{array}$ & $\begin{array}{l}\text { con- } \\
\text { tent }\end{array}$ & $\begin{array}{c}\text { devia- } \\
\text { tion }\end{array}$ & $\begin{array}{l}\text { con- } \\
\text { tent }\end{array}$ & $\begin{array}{c}\text { devia- } \\
\text { tion }\end{array}$ & $\begin{array}{c}\text { conten } \\
t\end{array}$ & $\begin{array}{c}\text { deviati } \\
\text { on }\end{array}$ \\
\hline Humidity, $g$ & 90.4 & 91.8 & -0.02 & 89.0 & -1.4 & 86.0 & -4.4 & 93.0 & +2.6 \\
\hline Protein, $\mathrm{g}$ & 1.8 & 1.0 & -0.67 & 1.3 & -0.5 & 1.4 & -0.4 & 0.6 & -1.2 \\
\hline Fat, g & 0.2 & 0.1 & -0.08 & 0.1 & -0.1 & 0.2 & 0 & 0.3 & +0.1 \\
\hline $\begin{array}{l}\text { Carbohydrates } \\
\text { general, } g\end{array}$ & 4.7 & 4.7 & -0.07 & 6.2 & +1.5 & 8.2 & +3.5 & 4.6 & -0.1 \\
\hline Starch, $\mathrm{g}$ & 0.1 & 0.1 & -0.05 & 0.2 & +0.1 & 0.3 & +0.2 & 0.0 & -0.1 \\
\hline $\begin{array}{l}\text { Food } \\
\text { fiber, g }\end{array}$ & 2.0 & 2.0 & +0.6 & 0.8 & -1.2 & 3.0 & +1.0 & 1.0 & -1.0 \\
\hline $\begin{array}{l}\text { Organic acids, } \\
\text { g }\end{array}$ & 0.3 & 0.1 & -0.08 & 0.2 & -0.1 & 0.2 & -0.1 & 0.1 & -0.2 \\
\hline Ash, g & 0.7 & 0.6 & -0.2 & 0.7 & 0 & 1.0 & +0.3 & 0,4 & -0.3 \\
\hline \multicolumn{10}{|c|}{ Mineral substances, $\mathrm{mg}$} \\
\hline $\mathrm{Na}$ & 13.0 & 4.0 & -9.0 & 30.0 & +17.0 & 4.0 & -9.0 & 2.0 & -11.0 \\
\hline $\mathrm{K}$ & 300 & 204.0 & -96.0 & 234.0 & -64.0 & 175.0 & -125.0 & 238.0 & -62 \\
\hline $\mathrm{Ca}$ & 48.0 & 25.0 & -23.0 & 46.0 & -2.0 & 31.0 & -17.0 & 15.0 & -33.0 \\
\hline $\mathrm{Mg}$ & 16.0 & 14.0 & -2.0 & 26.0 & +10.0 & 14.0 & -2.0 & 9.0 & -7.0 \\
\hline $\mathrm{P}$ & 31.0 & 25.0 & -6.0 & 40.0 & +9.0 & 58.0 & +27.0 & 12.0 & -19.0 \\
\hline $\mathrm{Fe}$ & 0.6 & 0,4 & -0.2 & 0.6 & 0 & 0.8 & +0.2 & 0,4 & -0.2 \\
\hline \multicolumn{10}{|c|}{ Vitamins, mg } \\
\hline$\beta$-carotene & 0.06 & 1.5 & +1.44 & 1.1 & +1.04 & 0.001 & -0.059 & 0.03 & -0.03 \\
\hline $\mathrm{B}_{1}$ & 0.03 & 0.05 & +0.02 & 0.1 & +0.07 & 0.05 & +0.02 & 0.03 & 0 \\
\hline $\mathrm{B}_{2}$ & 0.07 & 0.06 & -0.01 & 0.02 & -0.05 & 0.02 & -0.05 & 0.03 & -0.04 \\
\hline $\mathrm{PP}$ & 0.9 & 0.7 & -0.2 & 1.0 & +0.1 & 0.5 & -0.4 & 0.7 & -0.2 \\
\hline $\mathrm{C}$ & 60.0 & 8.0 & -52.0 & 5.0 & -55.0 & 10.0 & -50.0 & 15.0 & -45.0 \\
\hline $\begin{array}{l}\text { Energy } \\
\text { value, kcal }\end{array}$ & 28.0 & 22.0 & -6.0 & 30.0 & -1.0 & 41.0 & +13.0 & 24.0 & -4.0 \\
\hline
\end{tabular}

Therefore, by the method of selection of components, promising ingredients were selected to enrich traditional recipes for minced meat. It has been established that white cabbage, zucchini, carrots and pumpkin are applicable as rational raw materials [14, 15]. Cilantro is used for national mince

Thus, on the basis of organoleptic and physicochemical studies for the production of model minced meat selected: carrots, white cabbage, cilantro and pumpkin.

Mathematical formulation of the problem for the preparation of an optimal recipe

Given: Product quality standard vector:

etalon $=\langle$ etalon $(j)>. j=1, M$

where, etalon (1) - proteins $(\mathrm{g})$ in $100 \mathrm{~g}$ of the product,

etalon (2) - fats $(\mathrm{g})$ in $100 \mathrm{~g}$ of the product,

etalon (3) - carbohydrates ( $\mathrm{g}$ ) per $100 \mathrm{~g}$ of the product,

etalon (4) - energy value ( $\mathrm{kcal}$ ) per $100 \mathrm{~g}$ of product,

etalon (5) - vitamin B1 (mg) in $100 \mathrm{~g}$ of the product,

etalon (6) - vitamin B1 (mg) in $100 \mathrm{~g}$ of the product,

etalon (7) - vitamin $\mathrm{C}(\mathrm{mg})$ per $100 \mathrm{~g}$ of the product,

etalon (8) - vitamin A (mg ret.equiv) / $\beta$ in $100 \mathrm{~g}$ of the product,

etalon (9) - calcium (mg) in $100 \mathrm{~g}$ of product,

etalon (10) - vitamin $\mathrm{E}$ (mg current equiv.) In $100 \mathrm{~g}$ of the product, 
etalon (11)- phosphorus (mg) in $100 \mathrm{~g}$ of the product, etalon (12) - magnesium ( $\mathrm{mg}$ ) in $100 \mathrm{~g}$ of the product, etalon (13) - iron (mg) in $100 \mathrm{~g}$ of the product,

etalon (14) - dietary fiber, g per $100 \mathrm{~g}$ of the product, a set of ingredients:

$\operatorname{Ingr}(i)=\langle\operatorname{ingr}(i, j)>i=1, N j=1, M$

where, ingr $(i, j)$ is the $j$-th quality indicator of the $i$-th ingredient.

The set of quality indicators of ingredients coincides with the quality indicators of the standard.

Define: vector $\mathrm{X}=\langle\mathrm{x}(\mathrm{i})\rangle \mathrm{i}=1, \mathrm{~N}$

where $x$ (i) is the share of the $i$-th ingredient in the blend of the recipe, in $\%$, and the values of these shares can only be taken from the set $0,1,2,3$. Thus, the solution is sought with an accuracy of up to one percent.

$$
q u p(j)=\sum_{i=1}^{N} \operatorname{ingr}(i, j) * x(i)
$$

A valid solution:

An admissible solution is the $\mathrm{k}$-th variant of the vector for which it is true:

$$
\begin{gathered}
\sum_{i=1}^{N} x(k, i)=100 \\
\forall k \forall i \text { minen (i) }<=x(k, i)<=\operatorname{maxen}(\mathrm{i})
\end{gathered}
$$

where minen (i), maxen (i) are the minimum and maximum allowable ingredient in the blend, respectively (set by the technologist).

Optimality criterion:

Two variants of the criterion are considered:

1. Criterion 1. Evaluates the normalized difference between the standard and the blend:

$$
Q I=\sqrt{\sum_{j=1}^{M}(\operatorname{etalon}(\mathrm{j})-\mathrm{qup}(\mathrm{j}))^{2}} / \text { etalon }(\mathrm{j})^{2}
$$

2. Criterion 2. Assesses the component with the maximum normalized absolute deviation from the corresponding reference:

$$
Q^{2}=\max _{j} \frac{\mid \text { etalon }(\mathrm{j})-\mathrm{qup}(\mathrm{j}) \mid}{\operatorname{etalon}(\mathrm{j})}
$$

Optimal solution:

1. The optimal solution 1 is the admissible vector $\mathrm{X}(\mathrm{k})$ that minimizes $\mathrm{Q} 1$ :

$$
Q 1=\min _{k} Q 1(k, X(k))
$$

2. An optimal solution 2 is an admissible vector $\mathrm{X}(\mathrm{k})$ that minimizes $\mathrm{Q} 2$

$$
Q^{2}=\min _{k} Q 2(k, X(k))
$$

Solution of the task:

The problem posed in its class belongs to the problems of integer nonlinear mathematical programming. To solve it, an algorithm and a program have been developed that implement the scheme of directed formation of acceptable options with the elimination of unacceptable ones. The program is implemented on the $\mathrm{C}++$ Builder 6.0 platform / Figure 1 shows the interface of the initial stage of solving the problem. 

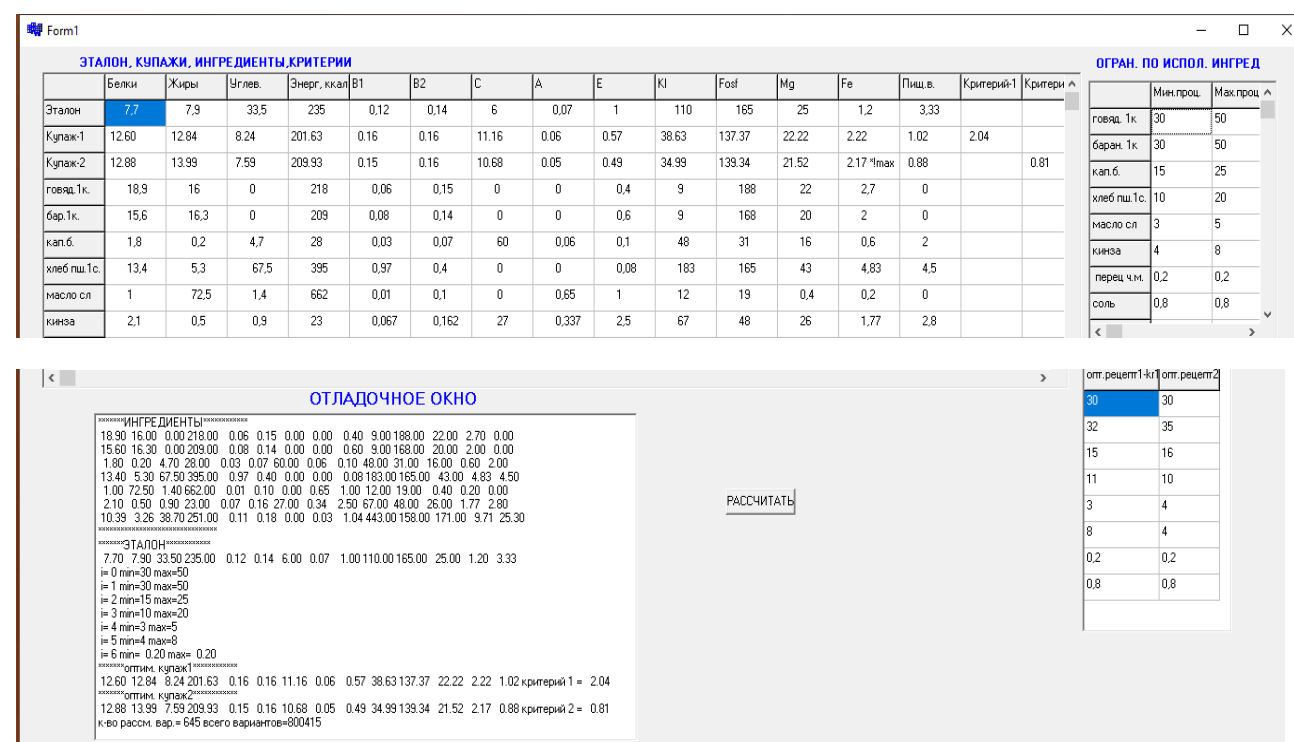

As a result of mathematical programming, the optimal variants of the recipe of the model meat and vegetable mince were determined, which is optimized for the diet of 7-11 year old students. The developed recipe is shown in Table 3.

Table 3. Optimized recipe for meat and vegetable model minced meat.

\begin{tabular}{|l|c|c|c|}
\hline \multirow{2}{*}{\multicolumn{1}{|c|}{ Product name }} & \multicolumn{2}{c|}{ Blend, \% } & \multirow{2}{*}{ Net, $\mathbf{g}$} \\
\cline { 2 - 3 } & min & max & \\
\hline Category 1 beef & 30.0 & 30.0 & 30.0 \\
\hline Lamb 1 category & 32.0 & 35.0 & 33.5 \\
\hline White cabbage & 15.0 & 16.0 & 15.5 \\
\hline Wheat bread 1 grade & 11.0 & 10.0 & 10.5 \\
\hline Butter & 3.0 & 4.0 & 3.5 \\
\hline Cilantro & 8.0 & 4.0 & 6.0 \\
\hline Ground black pepper & 0.2 & 0.2 & 0.2 \\
\hline Salt & 0.8 & 0.8 & 0.8 \\
\hline Total & 100 & 100 & 100 \\
\hline
\end{tabular}

The nutritional and energy value of the optimized recipe for meat and vegetable model minced meat is given in table. four. 
Table 4. Nutritional and energy value of the optimized formulation of meat and vegetable model minced meat.

\begin{tabular}{|l|c|c|c|}
\hline \multicolumn{1}{|c|}{ Name of nutrients } & Reference & Sample & Deviations, \% \\
\hline Calorie content (kcal) & 235 & 201.63 & -14.2 \\
\hline Proteins (g) & 7,7 & 12.6 & 67.27 \\
\hline Fat $(\mathrm{g})$ & 7.9 & 12.88 & 63.04 \\
\hline Carbohydrates (g) & 33.5 & 8.24 & -75.4 \\
\hline Vitamin B1 (mg) & 0.12 & 0.16 & 33.3 \\
\hline Vitamin B2 (mg) & 0.14 & 0.16 & 14.28 \\
\hline Vitamin C (mg) & 6 & 11.16 & 86.0 \\
\hline Vitamin A (mg ret.eq) / $\beta$ & 0.07 & 0.54 & 671 \\
\hline $\begin{array}{l}\text { Vitamin E (mg current } \\
\text { equiv.) }\end{array}$ & 1.0 & 0.57 & -43.0 \\
\hline Calcium (mg) & 110 & 38.63 & -64.9 \\
\hline Phosphorus (mg) & 165 & 137.37 & -16.74 \\
\hline Magnesium (mg) & 25 & 22.22 & -11.1 \\
\hline Iron (mg) & 1,2 & 2.22 & 85.0 \\
\hline Food fiber, g & 10 & 1.02 & -89.8 \\
\hline
\end{tabular}

Designed by the meat and vegetable model minced meat in terms of protein and fat content corresponds to the daily needs of 7-11 year old students. Minced meat is enriched with $\mathrm{B}$ vitamins (B1, B2), C and A, as well as iron. When preparing dishes from this minced meat, it is necessary to combine it with vegetables and cereals (as a side dish).

The obtained results of studies on the development of recipes for meat-vegetable model minced meat are consistent with the publications of a number of domestic and foreign authors who argue the advisability of including vegetable components in the minced meat recipe, as well asthe prospects of using in the production of functional minced meat semi-finished products with the addition of processed products of leguminous crops, wheat fibers and other components have been proved [22, 23, 24].

In the field of creating completely new food products with new food and biological properties, various legumes are actively used. Beans are considered one of the most widespread and demanded ones. Its protein surpasses many types of meat and fish in its nutritional value. Beans contain many micro- and macroelements, as well as vitamins $\mathrm{B}_{1}, \mathrm{~B}_{2}, \mathrm{~B}_{3}, \mathrm{~B}_{6}, \mathrm{C}, \mathrm{E}, \mathrm{K}$, PP, essential amino acids, carotene, etc. [25].

The creation of functional products based on a combination of meat and vegetable raw materials is one of the areas of resource-saving technology in the meat industry. The use of leguminous crops with a high biological value and having a positive effect on the functional and technological properties of minced meat semi-finished products: it is widely used in production and is considered one of the promising areas [26].

Meat is a source of biologically complete proteins, minerals and vitamins; the fats in meat have sufficient biological effectiveness and determine the high energy value of meat products. Among different types of meat, mutton, and especially lamb, are distinguished by good digestibility and dietary properties.[27].

\section{Conclusion}

Thus, as a result of the conducted studies, it can be noted that the optimized recipe of enriched cabbage casserole in terms of the ingredient composition will be as close as possible to the reference sample, which is $10 \%$ of the daily set of food products, and in terms of nutritional and energy value, it corresponds to $3-4 \%$ of the nutritional value 1 meals from the daily diet of a schoolchild in the age category of 7-11 years. 


\section{References}

1. Decree of the President of the Russian Federation (as amended on 01.07.2014) "On the approval of the Concept of the demographic policy of the Russian ind.1351 09.10 (2007)

2. Federation for the period up to 2025 "Federal Law" On the quality and safety of food products "dated, ind. 29-FZ 02.01(2000)

3. Decree of the Government of the Republic of Tajikistan dated December 31, "On Approval of the Strategy for Nutrition and Physical Activity in the Republic of Tajikistan for 2015-2024" ind. 808 (2014)

4. D.F. Chebotarev, Modern dietetics. Opportunities in terms of correction of the leading risk factors for the development of chronic diseases / D.F. Chebotarev https://yandex.ru/images/search. Date of treatment 04.26 (2021)

5. E.V. Chebotareva, Development of the technology of canned lamb meat, nutritiously adequate to the specifics of the nutrition of young children: Author's abstract. dis. for a job. uch. step. Cand. tech. sciences. All-Russian Research Institute of Meats. industry, Moscow, 26 (2004)

6. Yu.V. Konev, E.D. Li, O.O. Kuznetsov, I.A. Trubnikova, Peculiarities of nutrition in old and senile age / breast cancer. Selected lectures for family doctors. 17, 2, 145-149 (2009)

7. V.A. Konyshev, All about proper nutrition, (M.: Olma-Press, 2001)

8. L.P. Khoroshina, Proper nutrition of an elderly person, (SPb.: Dilya, 2004)

9. Methodical instructions for the determination of biochemical parameters of oil and oil seeds, (Krasnodar: VNIIMK, 1986)

10. V.A. Vygodin, G.B. Zinyukhin et al., Extrusion technique and technology: state and prospects Food industry, ind.7, 39-42 (1995)

11. AM Brazhnikov, I.A. Rogov, On the possibility of designing combined meat products / // Meat Industry of the USSR. ind. 5 23-25 (1985)

12. G.V. Kovrov, Soybean products food of the new millennium Food industry, ind. 2 (1997)

13. AB Kozmava, G.I. Kasyanov, V.V. Lissitzky New in the preparation of pates Izvestiya vuzov. Food technology, ind. 1 (1998)

14. NN Lipatov, I.A. Rogov Methodology for designing food products with the required complex of nutritional value indicators Izv. universities, ser. food. technologies. ind. 2 9-15 (1987)

15. Medical and biological requirements and sanitary standards for the quality of food raw materials and food products. Iz-in standards 35 (1990)

16. T.G. Homeland, G.A. Wux. Tasting analysis of products Kolos, 160 (1994)

17. S.N. Parfenova, S.A. Ivanov New technology for the production of canned minced meat. Abstracts. report International Symposium. Vladivostok, 284-286 (2000)

18. AT Vasyukova. IA Bogonosova, AV Moshkin. The use of promising ingredients in the development of food products In the collection: Innovative technologies in agriculture, veterinary medicine and food industry collection of scientific articles based on the materials of the 84th scientific-practical conference. Stavropol, StGAU, 287-291 (2019)

19. AT Vasyukova Collection of recipes for dishes and culinary products of the cuisines of the peoples of Russia for public catering enterprises. Collection. 212 (2014)

20. MA Nikitina, AN Zakharov, VV Nasonova, AB Lisitsyn, Theory and practice of meat processing, ind. 3 63-77 (2017)

21. EV Semenov, AA Slavyansky, VV Ilyina Modeling the growth of sucrose crystals from its solutions/ Sugar. ind. 4 37-40. (2004)

22. ON Samchenko Legumes: prospects of use for optimizing the chemical composition of semi-finished meat products Science and modernity. 28 172-176 (2014) 
23. K. Monastyrsky Functional Nutrition: the foundation of the foundation of absolute health and longevity Lyndhurst. USA: Ageless Press, 340 (2004)

24. MB Roberfroid British J. Nutrition. ind. V. 88. 2 133-138 (2002)

25. S Seena, KR Sridhar Physicochemical, functional and cooking properties of under explored legumes, Canavalia of the southwest coast of India Food Res. Int. ind. 7 803-814 (2005)

26. E.V. Mikhaleva, Yu.A. Moscow Economic Journal, ind. 4 1-8 (2018)

27. V.A. Litvinov Formulation development and commodity assessment of semi-finished meat products using vegetable raw materials Diss. Cand. tech. sciences. Moscow, 151 (2012) 